\title{
Momordica Charantia (Bitter Melon): Safety and Efficacy During Pregnancy and Lactation
}

\author{
Nkechi Enwerem ${ }^{1}$, Priscillia Okunji ${ }^{1}$, Ntekim Oyonumo ${ }^{1} \&$ Amos Samson ${ }^{2}$ \\ ${ }^{1}$ Division of Nursing, Howard University, Washington, District of Columbia, USA \\ ${ }^{2}$ Department of Pharmaceutical Sciences, Cederville University, Ohio, USA \\ Correspondence: Nkechi Enwerem, Division of Nursing, Howard University, Washington, District of Columbia, \\ USA.
}

Received: August 1, 2018

Accepted: August 16, 2018

Online Published: August 21, 2018

doi:10.20849/ijsn.v3i2.454

URL: https://doi.org/10.20849/ijsn.v3i2.454

\begin{abstract}
Background: The leaf, fruit ,and bark of Momordica charantia (MC)(Common name. Bitter Melon). (Cucurbitaceae) has been used extensively in folk medicine as a remedy for diabetes. Biological and pharmacological activities attributed to different parts and extracts of these plants include anti-HIV, wound healing, anti-helmintic, anti-genotoxicity, larvicidal, antiviral, antimicrobial, anti-obesity, antifertility, anticancer, antidiabetes, antidiarrheal

In Nigeria, a decoction of the leaves or bark is used in folk medicine to manage diabetes. Pregnant and lactating women have been observed, consuming the extract of MC for its folkloric belief as an antidiabetic agent. But its potential for toxicity when administered during pregnancy, lactation and breast feeding has not been completely investigated. The present study was aimed to review the literature for evidence on the use, safety, efficacy and pharmacology of Momordica charantia during pregnancy and lactation.

Methods: Seven electronic databases including the Napralert database were searched. Data were compiled based on the grade and evidence found.

Results: There were no scientific evidence to support the use of Momordica charantia during pregnancy and lactation. However animal studies in both rodents and primates show that the plant extract, induce abortion. In males, seed extracts of M.charantia, showed indirect evidence of reduced availability of pituitary gonadotrophs necessary for spermatogenesis.

Conclusion: Caution should be exercised with the use of Momordica charantia during pregnancy and lactation till human research is conducted to determine its safety. There is a need to be cautious when using preparations containing Momordica charantia. Implications for Nursing: Findings can be utilized by community health nurses and policy makers to advice on the use of Momordica charantia during pregnancy, lactation and in males in their reproductive life.
\end{abstract}

Keywords: Momordica charantia, safety, efficacy, pregnancy, lactation

\section{Introduction}

Medicinal plants have formed the basis of health care throughout the world since the earliest days of humanity and are still widely used with considerable importance in international trade (Ahvazia et al, 2012). In certain African countries, however, up to $80 \%$ of the population still relies exclusively on plants as a source of medicines (WHO, 2005). Therefore, the continuous evaluation of these botanicals for safety/toxicity using different animal models is important.

Momordica charantia is a tropical plant belonging to the family Cucurbitaceae. The plant is a native of South-east Asia, Africa and the Caribbean (Aiyelaagbe et al., 2010). It is a creeping plant and is widely distributed in West Africa, Indian and Japan (Kumar, 2010). Momordica Charantia or Bitter Melon, also known as balsam pear or Karela, is a Tropical vegetable, is a common food in Indian cusine and has been used extensively in folk medicine as a remedy for diabetes. The Latin name Momordica means "to bite" (referring to the jagged edges of the leaf, which appear as if they have been bitten). (Kumar, 2010) 
Momordica charantia is extensively used in traditional medicine and has become a great contributor of chemicals in modern medicine. Various parts of the plant have been investigated for biological activity. The medicinal utilities have been described, especially for leaf, fruit and bark. The bark and leaf extracts have been therapeutically used as folk medicine for abortifacient, anthelmintic, aphrodisiac, burn, catarrh, constipation, digestion, demulcent, dermatosis, diabetes, diarrhea, dyspepsia, eczema, emetic, emmenagogue, emollient, fever, febrifuge, hemorrhoids, hepatitis, hypoglycemic, inflammation (liver), leprosy, leucorrhoea, leukemia, malaria, menstrual colic, pain, pruritus, purgative, rheumatism, scabies, skin, tumor, wound, vaginitis, vermifuge, cancer (breast), food, glucosuria, halitosis, hematuria, polyuria, refrigerant, bite (snake), anemia, colitis, kidney (stone), sterility (female), dysentery, gonorrhea, appetite stimulant, insecticide, laxative, rage, rhinitis, contraceptive, dysmenorrhea, fat loss, galactagogue, gout, hydrophobia, piles, pneumonia, psoriasis, sore, asthma, headache, scald, sprue, stomachache, cold, cough, hypertension, tonic gallbladder, contusions, lung, measles, suppurative, rheumatoid arthritis and lupus (Kumar, 2010)

M. charantia is principally used in West Africa as a taenifuge as well as in the treatment of fever (Burkil, 1985). Medicinally, the plant is widely used for therapeutic purposes. A tea prepared from the leaf is used for diabetes, to expel intestinal gas, to promote menstruation, and as an antiviral agent against measles, hepatitis, and feverish conditions (Sofowora, 2006; Mustafa et al., 2014). It is used tropically for sores, wounds, and infections and internally and externally for worms and parasites and to treat colic (Sofowora, 2006).

Biological and pharmacological activities attributed to different parts and extracts of these plants include anti-HIV (Bourinbaiar et al., 1995), wound healing(Sankaranarayanan et al., 1993 ), anti-helmintic (Lal et al., 1976 ), anti-genotoxicity (Balboa et al., 1992 ), larvicidal (Singh et al.,2006 ), antiviral (Nadkarni et al., 1993 ), antimicrobial (Sankaranarayanan et al., 1993 ), anti-obesity (Nerurkar et al., 2005), antifertility (Naseem, 1998 ), anticancer (kumar et al., 2010 ), antidiabetes(Shetty, 2005), antidiarrheal (Bakare et al., 2011)

Chemical investigation of MC, reveals the presence of dihydroxy-5 $\beta, 19$-epoxycucurbita-6,(23E)-diene; charantin, charine, diosgenin, lanosterol, lauric acid, linoleic acid, gentisic acid, gypsogenin and cryptoxanthin. Other classes of compounds, such as cucurbitins, cucurbitacins, cucurbitanes, cycloartenols, elaeostearic acids, erythrodiol, galacturonic acids, goyaglycosides, goyasaponins, guanylate cyclase inhibitors, hydroxytryptamines, karounidiols, momorcharasides, momordenol, momordicilin, momordicins, momordicinin and momordicosides have been reported from this plant (Jianchao et al., 2008; Aiyelaagbe et al., 2010)

In Nigeria, decoctions and aqueous extract of MC are commonly used in the treatment of diabetes. Some women, have been seen taking aqueous extract of MC during pregnancy and lactation for management of diabetes (Osemene et al., 2011). This, calls for an in-depth understanding of its efficacy and potential for harm during pregnancy and lactation.

One of the ways to address these issues, is to do a systemic review of the literature. In this paper, we will review the effectiveness of Momordica charantia with emphasis on issues related to pregnancy, lactation and breast feeding. This paper, is a continuation of our research effort on the evaluation of the efficacy and safety of a series of commonly used Nigerian plants during pregnancy and lactation.

\section{Methods}

AHMED, CINAHL, Cochrane CENTRAL, Cochrane Library, Medline, Internet journals, Napralert database, Natural Medicines comprehensive database, and Natural standard were reviewed from inception to March 2017 for information on Momordica charantia as it relates to its use on "pregnancy", "lactation", and "breastfeeding". The Latin and common name of Momordica charantia were also used as keywords in the search.

Information on the safety of this herb was searched for in the Complete German Commission E Monographs compiled by the American Botanical Council and Global Information Hub On Integrated Medicine (GLOBinMED), Natural standard monograph, and Natural Medicines, comprehensive database. Also, the safety of the active constituent of the herb was also searched. The pertinent journals were collected and the results tabulated as grade for indications of use, level for safety of consumption during pregnancy and safety of consumption during lactation. The level of evidence for therapeutic use and evidence for harm were evaluated on 'Grades for evidence for efficacy' and levels for evidence for harm as displayed in Tables 1 and 2 respectively (Jean-Jacques et al., 2006; Howick 2009; Alper 2010; Ulbricht 2010). 


\section{Results}

Table 1. Grades for the evidence for efficacy

\begin{tabular}{lll}
\hline Studies & Grade & Reference \\
\hline AntiHIV & E & Bourinbaiar, 1995 \\
Wound healing & D & Sankaranarayanan, 1993 \\
Anti-helminthic & E & Lal,1976 \\
Anti-genotoxicity & E & Paul, 2010 \\
Larvicidal & E & Singh, 2016 \\
Antiviral & E & Nadkarni, 1993 \\
Antimicrobial & E & Sankaranarayanan,1993 \\
Antiobesity & E & Nerurkar 2005 \\
Antifertility & E & Naseem, 1998 \\
Anticancer & E & Kumar, 2010 \\
Antidiabetes & D & Shetty, 2005 \\
Antidiarrheal & D & Bakare et al., 2011 \\
Galactaogue & F & Kumar, 2010 \\
Antilipids & E & Kumar, 2010 \\
\hline
\end{tabular}

Extract of M. charantia has benefitted some people infected with HIV. (Aiyelaagbe et al., 2010). Extracts prepared from Momordica charantia plant increases insulin sensitivity and can lower elevated blood sugar levels (Aiyelaagbe et al., 2010)

Table 2. Level for evidence for harm

\begin{tabular}{lll}
\hline Studies & Levels & Reference \\
\hline Abortions & 3 & Kumar,2010 \\
Antiovulatory & 3 & Koneri,2006 \\
Suppresses sperm production & 3 & Yama, 2011 \\
Decreased production of estrogen and progesterone & 3 & Osonuga, 2014 \\
reversible histological alterations in the prostate and testes & 3 & Boetse, 2011 \\
Teratogenic & 3 & Nwachi, 2010 \\
Gross malformation of litters & 3 & Nwachi, 2010 \\
Transferred to breast milk & 3 & Kumar, 2010 \\
Favism & 2 & Kumar, 2010 \\
\hline
\end{tabular}

The seeds have shown to induce abortions in rats and mice while the root extract has shown a uterine stimulant effect in animals. The fruit and leaf of MC in vivo studies, produced antifertility effect in female animals. In male animals extracts from the plant, suppressed sperm production. The momorcharins a group of chemicall present in the plant, are effective in inducing early and mid term abortions, but have no signs of teratogenic effects (Kumar et al., 2010)

Oral administration of the aqueous leaf extract of M. charantia to Swiss albino rats in eight doses of the extract $(0.5-20 \mathrm{~g} / \mathrm{kg}$ body weights),produced no visible signs of toxicity in the animals except for an initial huddling observed at the highest dose of $20 \mathrm{~g} / \mathrm{kg}$ body weight. No mortalities were recorded in all the doses. Also,no toxic symptoms were observed and neither food nor water intake was found to be reduced during the period (4). Administration of the extracts to Swiss albino rats in six doses ranging from $0.5-5 \mathrm{~g} / \mathrm{kg}$ body weight, no visible signs of toxicity in the animals, although no toxic symptom or deaths were recorded at the lowest doses of the extract $(0.5-2.0 \mathrm{~g} / \mathrm{kg}$ body weight) via this route of administration. Animals on higher doses $(3-5 \mathrm{~g} / \mathrm{kg}$ body weight) were more agitated than those on the lower doses . The LD50 obtained via the i.p. route was $2790 \mathrm{mg} / \mathrm{kg}$ (4). Nwachi et al. (2010) reported that the safety of the water extract of the unripe fruit on pregnant Sprague Dawley rats. Extract was administered on days 7, 8, 9, 10, 11, 12, 13 and 14 of gestation. The litter size was determined for each group and the litters were examined for gross malformations. The gross and histological examinations of various organs of the litters were also carried out. Results show that $8.65 \%$ of the litters from experimental animals were malformed as against $1.62 \%$ of control. It also showed that $31.2 \%$ of all the malformed litters had multiple congenital malformations. It also showed that the experimental rats had nine 
resorption sites while control had none. This demonstrates that the water extract of Momordica charantia is teratogenic in Sprague(Nwachi et al., 2010)

The active chemicals in bitter melon have shown in animal studies to be transferred through breast milk; therefore, it is contraindicated in women who are breast feeding (Kumar et al., 2010)

\subsection{Parts Used}

Leaves, bark, seeds, and fruit of Momordica charantia

\subsection{Interactions}

May potentiate insulin and anti-diabetic drugs. May potentiate cholesterol-lowering drugs (Kumar et al., 2010)

\section{Discussion}

Momordica charantia, have been shown to possess some beneficial therapeutic effect. There are no strong clinical evidence supporting the use of MC in pregnancy or during lactation . Extracts of M. charantia showed some benefit with people infected with HIV (Aiyelaagbe et al., 2010). A recent scientific study confirmed that the extract of this plant increases insulin sensitivity and can lower elevated blood sugar levels (Miura et al., 2001)

Some scientific investigation, have shown ethanol and water extracts of the fruit and leaf administered orally, to be safe during pregnancy. However, other studies have shown otherwise. Toxicity studies caused death in laboratory animals when different extract s prepared from the leaves, bark, fruit and seed are administered intravenously or intraperitoneally. Greater toxicity resulted from extracts prepared from the fruit and seed compared with the leaf or aerial parts of the plant. The seed extract, induce abortions in rats and mice, while the

root extract, has caused some uterine stimulant effect in animals. The fruit and leaf of bitter melon in in vivo has demonstrated an antifertility effect in female animals; suppression of sperm in male rats. In folk medicine, Bitter melon is used to induce abortion. In addition to its documented weak uterine stimulant activity, it is, contraindicated during pregnancy. Momordica charantia, reduce fertility in both males and females, as a result, should not be used by those undergoing fertility treatment or seeking pregnancy. In a study where various extracts (ether, benzene and alcohol) of M. charantia seeds,were administered orally and intraperitoneally to male rats for 35 days, result, showed a reduced availability of pituitary gonadotrophs necessary for spermatogenesis. The intraperitoneal administration, increased cholesterol and Sudanophilic lipid (Kumar et al., 2010). The seed contains vicine and therefore can trigger symptoms of favism in susceptible individuals. Some vivo clinical studies have demonstrated low toxicity of all parts of the bitter melon plant when ingested orally(Kumar et al., 2010). Toxicity, have been reported in children who consume red arils of the seeds (Kumar et al., 2010).

No risk has been reported on the use of this herb through its traditional or common use. A more rigorous and well controlled- clinical research is needed before this herb can be used during pregnancy and lactation. It is important for consumers and clinicians to know that Momordica charantia has the potential to interact with some prescription medications May potentiate insulin and anti-diabetic drugs. May potentiate cholesterol-lowering drugs (Kumar et al., 2010)

\section{References}

Ahvazia, M., Farahnaz, K.S., Mohammad, M.C. Faraz, M., Mozaffariane, V.A., \& Hamideh, Z. (2012). Introduction of Medicinal Plants Species with the Most Traditional Usage in Alamut Region. Iranian Journal of Pharmaceutical Research, 11(1), 185-194.

About Herbs: Bitter Melon. (2018). Memorial Sloan-Kettering Cancer Center. Retrieved January 7, 2018, from http://www.mskcc.org/mskcc/html/69138.cfm

Aiyelaagbe, O.O., Oladosu, I.A., Olaoluwa, O.O., Aboaba, S.A., Oloyede, G.K., \& Onah, D.U. (2010). Chemical composition and cytotoxicity of the essential oil of Nigerian Momordica charantia (Hook). International Journal of Essential Oil Therapeutics, 4, 26-28.

Alper, B.S. (2010). Review of online evidence-based practice point-of-care information summary providers: response by the publisher of DynaMed. J Med Internet Res., 12(3), e39. https://doi.org/10.2196/jmir.1622

Bakare, R.I., Magbagbeola, O.A., Akinwande, A.I., Okunowo, O.W., \& Green, M. (2011, January). Antidiarrhoeal activity of aqueous leaf extract of Momordica charantia in rats. Journal of Pharmacognosy and Phytotherapy, 3(1), 1-7. 
Balboa, J.G., \& Lim-Sylianco, C.Y. (1992). Antigenotoxic effects of drug preparations Akapulko and Ampalaya. Philippine Journal of Science, 121(4), 399.

Boetse, Y.O., Ikechukwu, D.F., Olugbenga, O.A., Ayodele, O.A., \& Caramel, N.C. (2011). Histomorphological alterations in the prostate gland and epithelium of seminiferous tubule of Sprague-Dawley rats treated with methanolic extract of Momordica charantia seeds. Iran J Med Sci, 36(4), 266-272.

Bourinbaiar, A.S., \& Lee-Huang, S. (1995). Potentiation of anti-HIV activity of the anti-inflammatory drugs dexamethasone and indomethacin by MAP30, the antiviral agent from bitter melon. Biochemistry and Biophysics Research Communications, 208(2), 779. https://doi.org/10.1006/bbrc.1995.1405

Burkil, H.M. (1985). Useful plants of West Tropical Africa (2nd ed.). Kew Royal Botanical Garden, 597-599.

Globin Med. (2018). Retrieved February 1, 2018, from http://globinmed.com/

Howick, J., Chalmers, L., Glasziou, P., Greenhalgh, T., Heneghan, C., Liberati, A., ... Thornton, H. (2011). The 2011 Oxford CEBM Evidence Levels of Evidence (Introductory Document). Oxford Centre for Evidence-Based Medicine. Retrieved February 1, 2018, from http://www.cebm.net/index.aspx?o=5653

Jean-Jacques, D., Dugald, S., Daniel, P., Gideon, K., \& Edwards, M., (2006). Safety and efficacy of Black Cohosh ( Cimicifuga Racemosa) during Pregnancy and Lactation. Can J Clin Pharmacol, 13(3), 3257 -e261.

Jianchao, C., Renrong, T., Minghua, Q., Lu, L., Yongtang, Z., \& Zhongquan, Z. (2008). Trinorcucurbitane and cucurbitane triterpenoids from the roots of Momordica charantia. Phytochem, 69(4), 1043-1048. https://doi.org/10.1016/j.phytochem.2007.10.020

Koneri, R., Balaraman, R., \& Saraswati, C.D. (2006). Antiovulatory and abortifacient potential of the ethanolic extract of roots of Momordica cymbalaria Fenzl in rats. Indian J Pharmacol, 38(2), 111-114. https://doi.org/10.4103/0253-7613.24616

Kumar, D.S., Sharathnath, K.V., Yogeswaran, P., Harani, A., Sudhakar, K., Sudha, P., \& Banji, D. (2010). A Medicinal Potency of Momordica Charantia, 1(2), 18.

Lal, J., Chandra, S., Raviprakash, V., \& Sabir, M. (1976). In vitro anthelmintic action of some indigenous medicinal plants on Ascaridia galli worms. Indian Journal of Physiology and Pharmacology, 20(2), 64.

Miura, T., Itoh, C., Iwamoto, N., Kato, M., Kawai, M., Park, S., \& Suzuki, I. (2001). Hypoglucemic activity of the fruit of the Momordica charantia in type II diabetic mice. J Nutr Sci Vit., 47(5), $340-344$. https://doi.org/10.3177/jnsv.47.340

Mustafa, A.A., Fawibe, O.O., Ajiboye, A.A., \& Agboola, D.A. (2014). Ethnobotanical Survey of Medicinal Plants Used in the Treatment of Diabetes in Irepodun Local Government Area of Osun State, Nigeria. Greener Journal of Biological Sciences, 4(2), 59-68. https://doi.org/10.15580/GJBS.2014.2.010314006

Nadkarni, K.M. (1993). Indian Materia Medica. Popular Prakashan, 1, 805-806.

Naseem, M., Patil, S., Patil, S. et al (1998). Antispermatogenic and androgenic activities of Momordica charantia (Karela) in albino rats. J Ethnopharmacology, 61, 9-16. https://doi.org/10.1016/S0378-8741(98)00006-3

Nerurkar, P.V. et al. (2005). Microsomal Triglyceride Transfer Protein Gene Expression and ApoB Secretion are Inhibited by Bitter Melon in HepG2 Cells. J. Nutr., 135(4), 702-706. https://doi.org/10.1093/jn/135.4.702

Nwachi, E.O.U., \& Mcewen, C. (2009). Teratogenic effect of the water extract of bitter gourd (Momordica charantia) on the Sprague dawley rats. African Journal of Traditional, Complementary and African Alternative Medicines, 7(1), 24-33.

Osemene, K.P., Elujona, A.A., \& Ilori, M.O. (2011). A comparative assessmentof herbal and orthodox medicines in Nigeria. Res J Med Sci., 5(5), 280-285. https://doi.org/10.3923/rjmsci.2011.280.285

Osonuga, O.A., Osonuga, I.O., \& Osonuga, A. (2014). Oral administration of leaf extracts of Momordica charantia affect reproductive hormones of adult female Wistar rats. Asian Pac J Trop Biomed, 4(Suppl 1), S521-S524. https://doi.org/10.12980/APJTB.4.2014C939

Paul, A., Bandyopadhyay, S., Acharyya, P., \& Raychaudhuri, S.S. (2010). Studies on genetic diversity of twelve accessions of Momordica charantia L. using morphological, RAPD and SCAR Markers. Asian Journal of Plant Sciences, 9(8), 471. https://doi.org/10.3923/ajps.2010.471.478

Sankaranarayanan, J., \& Jolly, C.I. (1993). Phytochemical, antibacterial, and pharmacological investigations on Momordica charantia Linn., Emblica offid Gaertn and Curcuma longa Linn. Indian Journal of Pharmaceutical Science, 55(1), 6. 
Shetty, A.K., Suresh, K.G., Sambaiah, K., \& Salimath, P.V. (2005). Effect of bitter gourd (Momordica charantia) on glycaemic status in streptozotocin induced diabetic rats. Plant Foods Hum Nutr, 60(3), 109-112. https://doi.org/10.1007/s11130-005-6837-x

Singh, R.K., Dhiman, R.C., \& Mittal, P.K. (2006). Mosquito larvicidal properties of Momordica charantia Linn (Family: Cucurbitaceae). J Vect Borne Dis, 43, 88-91.

Sofowora, A. (2006). Medicinal Plants and Traditional Medicine in Africa (2nd ed.). Spectrum Books Ltd., Ibadan, Nigeria, pp. 151-153, 209-214.

Ulbricht, C. (2010). Natural Standard Herb \& Supplement Guide: An Evidence-Based Reference, 1e. Mosby Elsevier, Maryland Height, Missouri 63043.

World Health Organization. (2018). WHO traditional medicine strategy 2002-2005. Geneva: WHO. Retrieved June 13, 2018, from http://www.who.int/medicines/publications/traditionalpolicy/en/index.html

Yama, O.E., Duru, F.I., Oremosu, A.A., Noronha, C.C., \& Okanlawon, A. (2011). Suppressive effects of Momordica charantia on pituitarytesticular axis and sperm production in male Sprague-Dawley rats. Int $J$ Med Med Sci, 3(12), 354-350.

\section{Appendix}

Table 3. Grades for the evidence for efficacy

\begin{tabular}{|c|c|c|}
\hline Grade & Evidence & Interpretation \\
\hline A & $\begin{array}{l}\text { VERY STRONG } \\
\text { SCIENTIFIC EVIDENCE }\end{array}$ & $\begin{array}{l}\text { Statistically significant evidence of benefit from one or more } \\
\text { systemic reviews/meta-analysis }\end{array}$ \\
\hline B1 & STRONG EVIDENCE & $\begin{array}{l}\text { Statistically significant evidence of benefit from one or more } \\
\text { properly conducted random control trials (RCTs). }\end{array}$ \\
\hline B2 & GOOD SCIENTIFIC EVIDENCE & $\begin{array}{l}\text { Statistically significant evidence of benefit from one or more RCTs. } \\
\text { The RCTs, however, are either of small sample size OR have } \\
\text { discrepancies in their methodologies }\end{array}$ \\
\hline $\mathrm{C}$ & FAIR SCIENTIFIC EVIDENCE & $\begin{array}{l}\text { Statistically significant evidence of benefit from one or more cohort } \\
\text { studies OR outcome studies }\end{array}$ \\
\hline $\mathrm{D}$ & WEAK SCIENTIFIC EVIDENCE & Evidence from case series \\
\hline $\mathrm{E}$ & $\begin{array}{lll}\text { INDIRECT } & \text { AND/OR } & \text { CLINICAL } \\
\text { EVIDENCE } & \end{array}$ & $\begin{array}{l}\text { Evidence from case reports OR expert opinion OR laboratory } \\
\text { studies }\end{array}$ \\
\hline $\mathrm{F}$ & $\begin{array}{l}\text { HISTORICAL OR TRADITIONAL } \\
\text { EVIDENCE }\end{array}$ & $\begin{array}{l}\text { Historical or traditional use by medical professionals, herbalists, } \\
\text { scientists, or aboriginal groups. }\end{array}$ \\
\hline
\end{tabular}

Table 4. Level for evidence for harm

\begin{tabular}{lll}
\hline Level & Evidence & Interpretation \\
\hline $1 \mathrm{a}$ & STRONG SCIENTIFIC EVIDENCE & $\begin{array}{l}\text { Statistically significant evidence from one or more systematic } \\
\text { reviews or RCTs. } \\
\text { Statistically significant evidence from one or more cohort studies OR } \\
\text { control study. }\end{array}$ \\
1b & GOOD SCIENTIFIC EVIDENCE & $\begin{array}{l}\text { Evidence from one or more case series. } \\
\text { Evidence based on case reports. }\end{array}$ \\
$1 \mathrm{c}$ & WEAK SCIENTIFIC EVIDENCE & $\begin{array}{l}\text { Evidence based on scientific studies conducted on animals, insects or } \\
\text { microorganisms OR laboratory studies on human cells. }\end{array}$ \\
2 & VERY WEAK SCIENTIFIC EVIDENCE & Evidence based on scientific theory OR expert opinion. \\
3 & IN VITRO SCIENTIFIC EVIDENCE & No available information \\
4 & INDIRECT EVIDENCE &
\end{tabular}

\section{Copyrights}

Copyright for this article is retained by the author(s), with first publication rights granted to the journal.

This is an open-access article distributed under the terms and conditions of the Creative Commons Attribution license (http://creativecommons.org/licenses/by/4.0/). 